\title{
Whistleblowing System and Fraud Early Warning System on Village Fund Fraud: The Indonesian Experience
}

\author{
Sugeng Wahyudi ${ }^{1}$, Tarmizi Achmad ${ }^{1} \&$ Imang Dapit Pamungkas ${ }^{2}$ \\ ${ }^{1}$ Business and Economics Faculty, Universitas Diponegoro, Semarang, Indonesia \\ ${ }^{2}$ Business and Economics Faculty, Universitas Dian Nuswantoro, Semarang, Indonesia \\ Correspondence: Imang Dapit Pamungkas, Business and Economics Faculty, Dian Nuswantoro University, Semarang, \\ Indonesia. Tel: 62-8564-020-5628.
}

Received: July 31, 2019

Accepted: August 28, 2019

Online Published: September 8, 2019

doi:10.5430/ijfr.v10n6p211

URL: https://doi.org/10.5430/ijfr.v10n6p211

\begin{abstract}
This research aims to investigate the effectiveness of village fund fraud prevention models by analyzing the implementation of the Fraud Early Warning System (FEWS) and whistleblowing system to good village governance towards clean government. This study used a descriptive qualitative research method by conducting interviews to explore more information about the problems of preventing village fund fraud. The paradigm used is the interpretive and methodology paradigm used to express meaning is phenomenology to describe and explain how behavior in the implementation of FEWS and the whistleblowing system against village fund fraud. Determination of informants was carried out with a sequential technique, namely all village officials and communities involved in managing the process of allocating village funds in Sumowono Subdistrict, Central Java Province, Indonesia as research informants. The population of this study was 105 village officials and community members from 16 villages in Sumowono District. This study shows that in managing village fund fraud, complaints about village fund fraud were mainly driven by courage from the local community in their respective villages. The strategy to reduce fraud is to provide opportunities for the community to implement FEWS and the whistleblowing system as a preventive strategy to prevent village fund fraud. FEWS and wshistleblowing system activities in village funds also face various challenges. The implementation of the FEWS and the effective whistleblowing system, the fraudsters will think again whether to continue fraud or cancel the behavior.
\end{abstract}

Keywords: fraud early warning system, whistleblowing system, village fund fraud

\section{Introduction}

The phenomenon of village fund fraud has caused anxiety for the community and the government in general. According to CNN Indonesia (2018) the Indonesian National Police found around 214 cases of village fund fraud involving a budget of up to 3 million USD, from 2015 to 2017 and there were around 900 villages that had problems, the village head was arrested, due to misappropriating village funds. Indonesia Corruption Watch released 110 cases of village fund fraud and village fund allocation throughout 2016-2017, of the 110 cases, most were carried out by the village head. The government has established various regulations and guidelines related to village funds in the hope of facilitating the implementation of village fund management so that it does not create potential fraud in its implementation. Regulation of the Minister of Home Affairs of the Republic of Indonesia No. 37 year 2007 concerning Guidelines for Village Financial Management is expected to be able to realize effective and efficient financial management governance by having transparency, accountability and participation. Village funds that have been issued by the government since 2015 amounting to 8,4 billion USD, in 2015 amounting to 1,4 billion USD, 2016 amounting to 3,5 billion USD, 2017 amounting to 4,2 billion USD (Setkab, 2019). The total allocation of funds of 74,910 villages has made the Corruption Eradication Commission have a considerable task in its supervision, the greater the funds provided the greater the likelihood of fraud occurring.

According to the State Development Audit Agency (2015), the first few risks of village fund fraud are the use of the theft of cash on hand. Second, mark up and or kick back on the procurement of goods or services. This certainly can cause losses to village finance and reduce the ability of the government by carrying out its duties and functions. Third, the use of village assets for the personal benefit of village officials illegally, misuse or disappear. An in-depth study needs to be done regarding the potential for fraud in village financial management so that later anti-fraud 
strategies can be developed in managing village finances. Departing from this idea, this study wants to examine how anti-fraud methods and strategies can be recommended in preventing village fund fraud.

The preventive step to find village funds fraud is by identifying problems in the field and formulating the results of the identification to make an appropriate solution to make effective methods of preventing village funds fraud and in order to build good village governance. Fraud cannot be eliminated, but can be minimized. One factor by implementing is a whistleblowing system. Whistleblowing system is a container for a whistleblower to complain of fraud or violations committed by internal parties of the organization. This system really requires the participation of all organizational elements in the process of disclosure and reporting. With effective, transparent and responsible implementation, it will encourage and increase employee and community participation to report suspected frauds. The next factor is to prevent village fund fraud by implementing the Fraud Early Warning System (FEWS), which is a method and software that is useful for preventing and detecting fraud.

This study has a purpose to analyze FEWS, implementation of Whistleblowing Systems which became an effective and optimal method to prevent fraudulent management of village funds to assist government and village community programs in order to realize Good Village Governance towards Clean Government. Based on the description above, this research is urgent and very importarnt for further research, so far research on prevention of fraud in managing village funds is still very limited. In fact, cases of fraud in village fund management have often occurred and are likely to continue. The consequences are very large and very detrimental to society. This is important as an effort to prevent fraud in managing village funds. Prevention of village funds fraud that are currently not so effective and optimal and are still focused on the accountability of village funds. Fraud has spread throughout the world, but there is not much theoretical research that is relevant to village fund fraud. Research related to prevention of fraud previously was carried out by (Donelson, Ege, \& McInnis, 2016). Factors related to fraud prevention have been examined previously about the quality of internal control systems, compensation, compliance with accounting norms, and unethical behavior (Hollow, 2014; Andon, Free, \& Scard, 2015). However, there is still very little research to continue the analysis to a more in-depth stage of research on the effectiveness of village fund fraud prevention models by analyzing the impact of the FEWS and the implementation of whistleblowing systems to build good village governance towards clean government.

\section{Literature Review}

Act No. 6 year 2014 concerning villages has opened a new era in the development of villages in Indonesia. This Law provides a great opportunity to improve the welfare of the community, especially in rural areas. Village development has a very vital role in increasing national development and regional development because villages have the authority, duties, and obligations to regulate and manage the interests of their own communities (Wilopo, 2008). The potential for fraud that can be identified in making financial reporting such as manipulating financial statements, forgery, or changing records or supporting documents that are the source of the preparation of financial statements. The potential for fraud can be done by falsifying the proof of the transaction and making a report that is not in accordance with reality (Pamungkas \& Utomo, 2018). The potential for fraud can also be seen from village officials who manipulate data so that what is planned, carried out and reported to be inappropriate. Cases of misuse of village funds found include embezzlement, budget cuts, and making fictitious reports. Fraudulent act that is carried out in various ways cunningly and is deceptive and is often not realized by victims who are harmed (ACFE, 2016). There are three types of fraud, namely misuse of assets, fraudulent financial statements and corruption. Fraud of financial statements appears in the presentation of financial reports that are manipulated so that they do not reflect the actual conditions. As for a number of forms of corruption carried out by the village government, namely bribery, levies illegal, fictitious project procurement. excessive and project value bubbles.

Fraud prevention efforts are based on the Instruction Presiden Republik Indonesia Number 10 year 2016 concerning the Action of Prevention and Eradication of Corruption in 2016 and 2017 concerning strengthening the internal control system, namely optimizing the whistleblowing system, information disclosure in governance and transparency and accountability in financial management. According to Elias (2008) the Whistleblowing System can be through internal or external channels. Reporting violations through internal channels occurs when employees know of fraud committed by other employees and report the fraud to their superiors. Meanwhile, whistleblowing through external channels arises when employees are aware of fraud committed by their organization or members of their organization, and they choose to report error to external parties or law enforcement because the fraud is endangering the public. Park and Blenkinsopp (2009) illustrate that there are three whistleblowing reporting lines, namely anonymous and identified, formal and informal, and internal and external. Violation reporting behaves differently in choosing reporting lines. Kaplan (2012) shows that the possibility of retaliation affects the intention of participants to report through anonymous or identified channels. Alleyne et al., (2013) suggested that perceived 
organizational support motivates individuals to report unethical behavior in their organizations. According Kaplan et al., (2009) empirically show effectiveness of anonymous reporting lines depends on the level or indication of fraud found and intention employees to report their findings to the appropriate recipients. Anonymous reporting lines are more effective in preventing fraud than those identified.

Whistleblowing according to the National Committee on Governance Policy (2008) is the disclosure of violations or disclosure of acts that are against the law, unethical or immoral actions, other organizations or institutions who can take action on the violation. Whistleblowing is defined as a disclosure of information carried out by members of an organization that performs fraudulent behaviour (Rehg et al, 2008). Whistleblowing system becomes very important in the disclosure of villlage fund fraud. According to Amri (2008) actions that can be reported or violated are acts which in the viewer's report are in good faith are acts of corruption, fraud, dishonesty, illegal acts, violations of tax provisions, or other laws and regulations. One of the most effective ways to minimize and fight fraud practices is that conflict with Good Corporate Governance is through whistleblowing system mechanisms (Amri, 2008).

\subsection{FEWS and Whistleblowing System in Preventing Village Fund Fraud}

One of the efforts of whistleblowing is by reporting violations or illegal actions inside or outside the company. Whistleblowing system is a way of reporting and disclosing facts about fraud as well as for detection, minimizing and then eliminating fraud committed by internal parties of the organization. According to Zimbelman Mark (2006), an effective whistle blowing system is a good tool for preventing and detecting fraud. The results Lee \& Fargher, (2013) study show that the whistleblowing system is a method that can be used to prevent fraud. In addition, the study of Dyck et al., (2010) shows that there was a decrease in the number of frauds after the whistleblowing system was conducted. Fraud practices that conflict with good corporate governance is through a whistleblowing system mechanism.

Priantara (2013) stated that various surveys in the United States showed that the whistleblower hotline system was the most important tool for preventing and detecting fraud because potential perpetrators were afraid to be reported if the system worked effectively. An effective Whistleblower hotline must protect the confidentiality of the reporter and ensure that there are no threats, intimidation, pressure or adverse actions to the reporter. An effective Whistleblowing system is thought to be able to reduce fraudulent village funds. This is because, if there is a party in the village government who acts as a whistleblowing and reports that there is an indication that there is an action leading to corruption or other fraud, then fraud can be prevented and investigated as soon as possible. The results of this study are similar (Titaheluw, 2011; Libramawan, 2014; Naomi, 2015) which shows that a whistleblowing system is one way that can be used to prevent fraud. The implementation of an effective whistleblowing system needs to be encouraged in every organization (KNKG, 2008).

The implementing of an effective whistleblowing system will prevent and reduce the occurrence of fraud, this is because organizational commitment of reporting protection policies, clear reporting mechanisms and evaluations and improvements made to improve the effectiveness of the whistleblowing system so that whistleblowers will be encouraged to act more in reporting fraud they know. Thus, a whistleblowing system is expected to reduce the culture of silence towards a culture of honesty and openness that is useful for preventing fraud. The results of research conducted by Agusyani (2016) found that whistleblowing had a significant influence on fraud prevention. So the better the application of whistleblowing systems within the organization is, the lower the level of village fund fraud.

\section{Methods}

This study uses a qualitative approach to identify, investigate, and explore the phenomenon of how the FEWS and whistleblowing system are implemented in preventing village fund fraud. This study has the aim of obtaining a subjective understanding of the ongoing process. So, that it uses the perspective of the interpretive paradigm. According Burrell and Morgan, (1979) the interpretive paradigm is the paradigm used to obtain a related subjective understanding that result from the process that occurs. The methodology used to express meaning is phenomenology, namely to describe and explain how the actors understand the implementation of the FEWS and the whistleblowing system against village fund fraud. The informants in this study were village officials and the community who worked on financial management of village funds. This research collects data openly with interview methods.

Determination of informants is done by sequential techniques, namely there is no limit in the selection of informants, the number of informants will increase until the information obtained is already not developed and the informants have reached a saturation point (Neuman 2014). Questions that are used as references can develop according to the situation and conditions in the field. The data collection technique begins with conducting interviews with informants. This study uses semi-structured interview techniques with flexible questions in accordance with the conditions in the 
field which aim to collect information on the implementation of the FEWS and the Whistleblowing System. The results of the interviews were then analyzed and concluded according to the answers from the informant. The location of the study is a case study with a focus on managing village funds in Sumowono District, Semarang city, Regency in Central Java Province, Indonesia. The reason underlying the location of this study was chosen, because it is a sub-district prone to fraud and there have been cases of fraudulent village funds by the village head in the sub-district, so that the government suffered heavy losses and village development did not go smoothly.

The population of this study was 105 village officials and community members from 16 villages in Sumowono District. The researcher chose convenience sampling technique. This is done on the basis of convenience, there are no criteria that are set according to the village apparatus including the village head, village treasurer, village secretary or head of development affairs or the community who are willing to respond (Utami, Jori, \& Hapsari, 2017). Steps in maintaining the reliability and validity of the qualitative data that has been collected, which must ensure validity the data, examine the results of transcription to ensure that no errors are made during the transcription process and answer some questions from friends to improve the accuracy of the research results (Creswell, 2012). Data analysis is the final step of the research before making conclusions. This study uses interative analysis which consist of there are three things in analyzing this model, namely reducing data and presenting data and verifying conclusions. This reseacrh is all carried out in an interactive form, with the process of collecting data as a cycle. After the data is collected in the form of data presentation, the next step is to reduce the data, because the data obtained from the interviewers turns out that so much is not all relevant to the problem. After the data has been reduced the verification step can be done. These steps are carried out repeatedly like a cycle and are stopped if there is a collection of previously obtained data.

\section{Result and Discussion}

Nine village officials were willing to report fraud and seven of them refused to report fraud if they found potential fraud. As the village secretary A said:

"...I will report fraud because I am also responsible for the fraud. I am sure I will do the right thing. If fraud occurs at the village level, I will definitely report. A fraud case will ultimately cause me to be responsible. So, why should I be afraid to report? I will definitely report."

The village secretary B stated that he was ready to report fraud in the administration of village funds:

"...when I found out there was potential for fraud in our village, I would immediately report it, with great hope as a form of prevention of fraud from an early age so that fraudulent village funds did not recur". When fraud occurs, we immediately report it. For example, when budget fraud is indicated, we are ready to report it because this case is not in accordance with the regulations. Everything must be based on regulations. Since 2015 we have been very enthusiastic about that. We all must stick to the rules."

The village secretary $\mathrm{C}$ also mentioned that fraud reporting prevented those who planned to cheat village funds.

"...The village head has appealed to the entire community to participate in overseeing the implementation of village funds, starting from the stage of fund disbursement, the use of funds and reporting of funds in each village and if it is found fraud is expected to immediately report it with the fraud early warning system. I am willing to report if I find fraud in village funds. Village fund reports must be transparent and free from fraud. Every year we make reports to the villagers. I consider that reporting fraud is useful because of the behavior according to religious teachings and the belief in doing good. Reporting fraud also helps enforce the law while helping to be accountable to the public."

In line with the results of the interview, village officials $\mathrm{K}, \mathrm{L}, \mathrm{M}, \mathrm{N}, \mathrm{O}$ and $\mathrm{P}$ also mentioned that they had the intention to report fraud with a media whistleblowing system as a deterrent effect on the perpetrators. They emphasized that fraudulent behavior of village funds violated the rules and endangered many parties. However, different from the previous villages, seven other villages in Sumowono Subdistrict still applied the whistleblowing system ineffectively. Village officials are still hesitant to report if there is fraudulent village funds because they do not want to report their superiors or colleagues and are apathetic about the whistleblowing system if fraud occurs. Treasurer of Village D discloses the following:

"... I have no intention of reporting. The government already has people who monitor these funds, such as the Police and the Corruption Eradication Commission. They keep an eye on them. They supervise closely every month."

Village finance staff I added:

"... I feel I don't have an intenton to report when there is fraud. A lot of people and everyone in the village will find a fraud case for village funds. We also feel that shame is in this village. In the village, everyone knows each other. So, when there is fraud village funds, I will not have the intention to report." 
This finding highlights the different intentions of village officials to report village funds fraud in Sumowono District. Some village officials have the intention of becoming reporters while some are unwilling to become fraudulent reporters of village funds. Intention is a determinant of someone's decision to do or not to behave. Theory of planned behavior states that intention is the main antecedent of behavior (Ajzen, 1991). As explained by this theory, someone with a positive attitude will have the intention to do a behavior, and vice versa. A positive attitude implies that they will report if they find fraud.

However, village officials from seven other villages in Sumowono Subdistrict were apathetic about reporting of village fund fraud. Village officials consider external supervision to be sufficient because ultimately village fund fraud will be revealed, implying that reporting of village fund fraud is unnecessary. They also did not have the intention to report fraud on village funds because they were hesitant to report their superiors or colleagues. When there was village fund fraud, village officials would take a personal approach to their colleagues who village fund fraud. If the perpetrators are willing to return the funds resulting from corruption, then they are forgiven. However, if it refuses then the legal process will continue, village officials will report of village fund fraud to the police for punishment. Following are the answers of village officials regarding the whistleblowing system they will use. The Village Treasurer K explained:

"...We are aware of village fund fraud, there are budget cuts down to the project. Furthermore, there are fictitious reports, there are programs that are not suitable, excessive mark-ups occur, this becomes a serious problem that must be followed up. I will hold a meeting to produce a consensus if there is village fund fraud. If successful, the case stops. However, if the perpetrator refuses to be held accountable, I will immediately report and bring this case to the police to be punished according to the applicable regulations."

The Village Secretary L also argued as follows:

"...I am determined to report a village fund fraud case to the Corruption Eradication Commission. I will analyze this case carefully because I do not want to be involved in unconfirmed cases. If I can confirm that the case is true, then I seriously report it. I believe they will follow up the report quickly. Management of village funds in accordance with procedures and good monitoring can reduce the possibility of potential fraudulent village funds. Villagers are expected to take part in monitoring the village funds so that village fund fraud can be minimized."

According to Elias (2008), whistleblowing reporting through internal channels arises when employees are aware of fraud committed by their colleagues and report such fraud to superiors. Meanwhile, external lines are used when employees choose to report fraud to external parties or law enforcers because the fraud is harmful to the public.

Support from the closest individuals such as family, colleagues and friends motivates village officials to report fraud. Some of our informants mentioned that their families supported their positive behavior, namely reporting fraud on village funds, if this report did not endanger village officials or their families. In addition, other village officials also supported the behavior because they considered being able to improve their village as long as the case was true. This support motivated village officials to report of village fund fraud. As said village treasurer P:

"...As long as it's good, my family supports me. Monitoring of village funds and the FEWS must run more optimally so that fraudulent village funds can be prevented and village development can take place more effectively."

The Village Secretary P also told us that his family and closest friends supported his decision to report fraud on village funds:

"...I am very confident that I will have support as long as it is true and not a lie. Reports must be in accordance with the facts. At present there are many dubious reports. When officials tried to confirm, it was revealed that the report did not correspond to reality."

However, several other village officials in Sumowono District did not have such support. Their families and colleagues do not support reporting decisions because they fear behavior will harm their village. This lack of support does not motivate village officials to report fraud on village funds. As stated by the village secretary G:

"...I will not report fraud on village funds because I am not sure the case I reported will be followed up, and I am afraid that the reported fraud of village funds cannot be kept confidential. Village funds make fear of family and coworkers. They worry that village funds are increasingly stringent regulations and regulations, tighter supervision. They worry that I will make an administrative mistake."

Village Secretary E provided information that he did not have family support to report fraud on village funds because he never told his family about work problems:

"...I have never reported any fraud in village funds, my principle is that work is not related to family." 
The Village Treasurer I also mentioned that other village officials did not directly support the decision to report fraud on village funds:

"...I have to clarify the case first. If there are indications of village fund fraud, it is definitely not intentional. It is very unlikely to manage large funds perfectly. We also do not fully understand the rules about village funds. If there are errors, including administrative or error will be punished, so we better not receive village funds."

As suggested by the Theory of Planned Behavior, when individuals believe that their environment accepts certain behaviors, they will have the intention to show that behavior (Ajzen, 1991). Our interview revealed that not all village officials in Sumowono Subdistrict believed that reporting of village fund fraud could be accepted in their environment. This is because they do not receive support from their family or colleagues. Village officials believe that the people closest to them fearing reporting fraud can endanger themselves, their coworkers, their families and the village community. However, most village officials believe that reporting fraud can be accepted in their environment because they receive support from their family and coworkers. Village officials believe that the people closest to them disagree if fraud is allowed because it will endanger their village. In conclusion, the people closest to them will support their decision to report fraud on village funds.

Regarding perceived behavioral control, village officials in Sumowono Subdistrict felt that a small proportion of village officials had the same opportunity to report if there was fraudulent village funds. Some village officials in Sumowono District informed that reporting fraud was easy because they had been advised to report if they found fraudulent village funds. As said village treasurer M:

"... Monitoring of village funds should prioritize fraud early warning systems as an aspect of preventing village funds. With the help of the police and all surrounding communities to conduct surveillance as well as whistleblowers. The serious aspects of prosecution are expected to be the last step in monitoring village funds with the aim of give a deterrent effect to anyone who will commit fraud. I have protection or not, I keep reporting it. When I find out there is fraudulent village funds, I will have the intention to report it to support the good village government."

However, village official $\mathrm{G}$ argue that reporting fraud in their village is difficult:

"...The implementation of the FEWS and whistleblowing system is not easy. If we can still make negotiations and agreements, we will consider. We are also not likely to report this embarrassing case. Protection is not a problem. If fully protected, we it remains awkward to report our own colleagues. We will hand it over to the public and the Corruption Eradication Commission."

According Ajzen, (1991) theory of planned behavior states that intentions in behavior is driven by how he feels ease or difficulty in behaving. When they believe that their behavior is a result of their self-control, these individuals will have the intention to show behavior. Intention to report village fund fraud shows the dynamics of the whistleblowing system. With the implementation of an effective Whistleblowing system, the fraudsters will think again whether to continue fraud or cancel the behavior. They will tend to be afraid if fraud is known and reported by the whistleblowers. But on the contrary, if there is no effective participation of the whistleblowers and Fraud Early Warning System, fraud will be easily carried out especially since the system of control and supervision of the village community has not been very good and there is no clear and strong legal protection for fraudulent whistleblowers. Thus making the whistleblower candidates afraid to report indications of fraudulent village funds that they found and chose to silence to be free from all risks

\section{Acknowledgements}

This Article is the result of research financed by the Directorate of Research and Community Service Directorate General of Research and Development Reinforcement Ministry of Research, Technology and Higher Eduction in accordance with the Contract of Research of Fiscal Year 2019. No: 257-02/UN7.P4.3/PP/2019 dated 1 April 2019.

\section{References}

Ajzen, I. (1991). The Theory of Planned Behavior. Organizational Behavior and Human Decision Processes.

Ajzen, I., \& Driver, B. L. (1992). Application of the theory of planned behaviour to leisure choice. Journal of Leisure Research, 24, 207-224. https://doi.org/10.1080/00222216.1992.11969889

Ajzen, I., \& Fishbein, M. (1975). Belief, attitude, intention and behavior: An introduction to theory and research. Reading, MA: Addison-Wesley.

Alleyne, P., Hudaib, M., \& Pike, R. (2013). Towards a conceptual model of whistle-blowing intentions among external auditors. The British Accounting Review, 45(1), 10-23. https://doi.org/10.1016/j.bar.2012.12.003

Association of Certified Fraud Examiners. (2018). Report to the Nations on Occupational Fraud and Abuse. 
Awang, Y., Ismail, S., \& Rahman, A. R. A. (2016). Measuring the Potential for Financial Reporting Fraud In a Highly Regulated Industry. The International Journal of Accounting and Business Society, 24(1), 81-98.

Beck, L., \& Ajzen, I. (1991). Predicting dishonest actions using the theory of planned behavior. Journal of Research in Personality, 25(3), 285-301. https://doi.org/10.1016/0092-6566(91)90021-H

Carpenter, T. D., \& Reimers, J. L. (2005). Unethical and fraudulent financial reporting: Applying the theory of planned behavior. Journal of Business Ethics, 60(2), 115-129. https://doi.org/10.1007/s10551-004-7370-9

Carrington, M. J., Neville, B. A., \& Whitwell, G. J. (2010). Why ethical consumers don't walk their talk: Towards a framework for understanding the gap between the ethical purchase intentions and actual buying behaviour of ethically minded consumers. Journal of Business Ethics, 97(1), 139-158.

Conner, M., \& Armitage, C. J. (1998). Extending the theory of planned behavior: A review and avenues for further research. Journal of Applied Social Psychology, 28(15), 1429-1464.

Harding, T. S., Mayhew, M. J., Finelli, C. J., \& Carpenter, D. D. (2007). The theory of planned behavior as a model of academic dishonesty in engineering and humanities undergraduates. Ethics \& Behavior, 17(3), 255-279.

Hays, J. B. (2013). An Investigation of Management Accountants Intention to Report Fraudulent Accounting Activity: Applying the Theory of Planned Behavior. Umi Disertation Publishing.

Henle, C. A., Reeve, C. L., \& Pitts, V. E. (2010). Stealing time at work: Attitudes, social pressure, and perceived control as predictors of time theft. Journal of Business Ethics, 94(1), 53-67.

Leung, K., Bhagat, R. S., Buchan, N. R., Erez, M., \& Gibson, C. B. (2005). Culture and international business: Recent advances and their implications for future research. Journal of International Business Studies, 36(4), 357-378. https://doi.org/10.1057/palgrave.jibs. 8400150

Machrus, H., \& Purwono, U. (2012). Behavioral Measurement based on Theory of Planned Behavior. Journal of Media Human Psychology, 12(1), 64-72.

McSwain, D. N., Glandon, S., \& Glandon, T. A. (2011). The Theory Of Planned Behavior: An Examination Of Governmental Financial Managers Intentions To Modify Internal Controls For E-Services. Review of Business Information Systems (RBIS), 12(1), 33-52. https://doi.org/10.19030/rbis.v12i1.4396

Pamungkas, I. D. (2018). Fraudulent Financial Reporting: An Application of Fraud Pentagon Theory to Association of Southeast Asian Nations Corporate Governance Scorecard. Journal of Advanced Research in Law and Economics, 9(5), 1729-1737. https://doi.org/10.14505//jarle.v9.5(35).26

Park, H., \& Blenkinsopp, J. (2009). Whistleblowing as planned behavior - A survey of South Korean police officers. Journal of Business Ethics, 85(4), 545-556. https://doi.org/10.1007/s10551-008-9788-y

Passow, H. J., Mayhew, M. J., Finelli, C. J., Harding, T. S., \& Carpenter, D. D. (2006). Factors Influencing Enginering Students'Decisions to Cheat By Type of Assement. Research in Higher Education, 47(6), 643-684

Ponnu, C. H. (2008). Corporate governance structures and the performance of Malaysian public listed companies. International Review of Business Research Papers, 4(2), 217-230.

Prabowo, H. Y., Syamsudin, M., \& Sriyana, J. (2012). Understanding Corruption from Behavioral Perspective: A Case Study of Yogyakarta Special Province. European Journal of Economics, Finance and Administrative Sciences, (55), 97-105.

Rustiarini, N. W., \& Sunarsih, N. M. (2015). Fraud and whistleblowing: Disclosure of accounting fraud by government auditors. Proceedings of the National Symposium on Accounting for XVIII, Medan.

Semendawai, A. H., Santoso, F., Wagiman, W., Omas, B. I., \& Susilaningtias, S. M. W. (2011). Understanding Whistleblowers. Jakarta: Witness and Victim Protection Agency (LPSK).

Singleton, T. W., \& Cisa, C. (2010). Top five fraud axioms IT auditors should know. ISACA J., 4.

Tuanakotta, T. M. (2010). Forensic accounting and investigative audits in the accounting department of the Indonesian faculty of economics. Jakarta: Accounting Department, Faculty of Economics, University of Indonesia.

Utomo, D., Pamungkas, I. D., \& Machmuddah, Z. (2018). The Moderating Effects of Managerial Ownership on Accounting Conservatism and Quality of Earnings. Academy of Accounting and Financial Studies Journal, 22(6), 1-11

Yoon, C. (2011). Theory of planned behavior and ethics theory in digital piracy: An integrated model. Journal of Business Ethics, 100(3), 405-417. https://doi.org/10.1007/s10551-010-0687-7 